\title{
Induction versus Progression of Brain Tumor Development: Differential Functions for the pRB- and p53-Targeting Domains of Simian Virus $40 \mathrm{~T}$ Antigen
}

\author{
M. T. SÁENZ ROBLES, ${ }^{1} \dagger$ H. SYMONDS,,${ }^{1,2}$ J. CHEN,${ }^{1} \ddagger$ AND T. VAN DYKE ${ }^{1,2 *}$ \\ Department of Biological Sciences, University of Pittsburgh, Pittsburgh, Pennsylvania, ${ }^{1}$ and Department of \\ Biochemistry and Biophysics, University of North Carolina at Chapel Hill, Chapel Hill, North Carolina ${ }^{2}$
}

Received 20 October 1993/Returned for modification 10 December 1993/Accepted 11 January 1994

\begin{abstract}
The ability of simian virus 40-encoded large $T$ antigen to disrupt the growth control of a variety of cell types is related to its ability to interfere with certain cellular proteins, such as p53 and the retinoblastoma susceptibility gene product (pRB). We have used wild-type and mutant forms of $T$ antigen in transgenic mice to dissect the roles of $\mathbf{p R B}, \mathbf{p 5 3}$, and other cellular proteins in tumorigenesis of different cell types. In this study, using a cell-specific promoter to target expression specifically to brain epithelium (the choroid plexus) and to $B$ and $T$ lymphoid cells, we characterize the tumorigenic capacity of a $T$-antigen fragment that comprises only the amino-terminal 121 residues. This fragment (dl1137) retains the ability to interact with pRB and p107 but lacks the p53-binding domain. While loss of the p53-binding region results in loss of the capacity to induce lymphoid abnormalities, $d l 1137$ retains the ability to induce choroid plexus tumors that are histologically indistinguishable from those induced by wild-type $T$ antigen. Tumors induced by $d l 1137$ develop much more slowly, however, reaching an end point at around 8 months of age rather than at 1 to 2 months. Analysis of tumor progression indicates that tumor induction by $d l 1137$ does not require secondary genetic or epigenetic events. Rather, the tumor growth rate is significantly slowed, indicating that the T-antigen C-terminal region contributes to tumor progression in this cell type. In contrast, the pRB-binding region appears essential for tumorigenesis as mutation of residue 107, known to disrupt pRB and p107 binding to wild-type $T$ antigen, abolishes the ability of the $d l 1137$ protein to induce growth abnormalities in the brain.
\end{abstract}

Transgenic mice provide a valuable system with which to explore mechanisms that regulate cell growth and differentiation. The ability to target the expression of test genes to specific cell types and developmental stages facilitates the rigorous assessment of regulatory pathways operative in each cell type in vivo. By this approach, simian virus 40 (SV40) large-T-antigen protein has been shown to be a particularly potent oncogene product that can disrupt the growth of more than 20 distinct cell types in mice $(1,28,29)$. The molecular mechanisms by which the 708-amino acid (aa) multifunctional $\mathrm{T}$ antigen subverts normal cell growth remain largely unknown, although correlations between transforming activity in cultured cells and the binding to specific cellular proteins have provided some clues. Studies in cell culture (reviewed in reference 23) and more recently in transgenic mice $(5,73)$ suggest that multiple distinct activities of $\mathrm{T}$ antigen are involved in growth disregulation. At least two transformation-related functions map within the amino-terminal 121 residues. The bettercharacterized of these corresponds to a domain (aa 105 to 114) that interacts with cellular proteins pRB (13) and p107 (19, 21). A second, distinct transformation-related activity appears to lie within the first 82 aa $(54,70,73,83)$, but the associated biochemical properties have not been defined. Complementation studies indicate that this region may interact with the

\footnotetext{
* Corresponding author. Mailing address: Department of Biochemistry and Biophysics, CB 3280, University of North Carolina at Chapel Hill, Chapel Hill, NC 27599. Phone: (919) 962-2145. Fax: (919) 962-4296. Electronic mail address: tavandy@email.unc.edu.

† Present address: Department of Pediatrics, University of Pittsburgh Medical School, Pittsburgh, Pa.

$\ddagger$ Present address: Department of Biology, Princeton University, Princeton, N.J.
}

adenovirus E1A-associated host protein, p300 (78). Interaction of the $\mathrm{N}$ terminus with a $185-\mathrm{kDa}$ protein has also recently been observed (65). A third T-antigen transformation function resides in the $C$-terminal half of the protein and corresponds to the p53-binding activity (lying within aa 351 to $626[38,51,57$, $63,82])$. Recent evidence suggests that other, less well characterized functions of $T$ antigen could also participate in transformation (16). Although each of these $\mathrm{T}$-antigen activities can be related to growth disregulation in one or another experimental system, their relative importance in cultured cells often depends on the particular cell line, cellular environment, and/or biological assay used (e.g., references 16, 23, 54, 68, 70, 74, and 83). As illustrated here, transgenic mice offer an alternative for evaluating the effects of this multipotent oncoprotein under natural cellular conditions.

Despite intensive investigation, the normal biological roles of $\mathrm{p} 53$ and pRB proteins are not clear. Both are thought to have roles in cell cycle control (for recent reviews, see references 27, 33, 41, 47, 60, and 62; see Discussion). The classification of $\mathrm{p} 53$ and $\mathrm{pRB}$ as negative growth regulators or tumor suppressors comes from the observations that the genes encoding these proteins often are lost or mutated in certain human tumors and that upon transfection into certain cultured cells, both genes can produce effects associated with the inhibition of cell growth (for reviews, see references 2, 27, 45, 47, 53, and 77). Within that general framework, it has been postulated that the ability of $T$ antigen (and certain other DNA tumor virus proteins) to stimulate cell growth reflects the release of a brake to cell growth normally imposed by proteins such as p53 and pRB (58). But that interpretation awaits experimental definition and verification.

Examining the various activities of $\mathrm{T}$ antigen in tumorigenesis provides a way to explore the normal function of its target 
proteins, such as pRB and p53. With this purpose in mind, we have developed a transgenic mouse system in which $\mathrm{T}$-antigen mutants that differ in their cellular protein-binding capacities are examined for tumorigenic activity in particular cell types. The system uses the cell-specific transcriptional control region from lymphotropic papovavirus (LPV) to direct expression to three cell types: the choroid plexus epithelium (CPE) of the brain, and B and T lymphoid cells $(4-6,20)$. In this system, wild-type SV40 T antigen expressed from the LPV promoter induces choroid plexus tumors in the majority of founder mice by around 4 weeks of life, apparently without the need for secondary somatic changes (6). Under circumstances in which the rapid development of CPE tumors (and resulting death of the animals) does not occur, wild-type $\mathrm{T}$ antigen also causes lymphoma of both B and T cells $(4,5,24,71)$. Our follow-up studies with mutant versions of $\mathrm{T}$ antigen have begun to dissect the particular regions of the viral protein, and thus the target cellular proteins, required for tumorigenesis in these three cell types $(5,73,76)$.

Here we describe analyses carried out with mutant $d l 1137$, which produces a form of $\mathrm{T}$ antigen (aa 1 to 121) that includes the pRB/p107-binding domain but lacks the p53-binding region. We were intrigued by preliminary evidence suggesting that this severely truncated version of $T$ antigen was not devoid of activity. Thus, $d l 1137$ and similar mutants were able to transform some albeit not all lines of cultured cells $(66-68,70)$. Our preliminary analysis of a small number of founder transgenic mice also indicated that this fragment of $T$ antigen could induce choroid plexus tumors but within a significantly delayed time frame compared with those induced by wild-type $T$ antigen (5). Although this experiment indicated that $d l 1137$ could somehow participate in tumorigenesis of at least one cell type, it did not allow us to determine the contributions of specific N-terminal and C-terminal functions to tumor development. For example, were compensating secondary somatic mutations of cellular factors required for tumor induction by $d l 1137$ ? If not, did the C-terminal region (including the p53-binding region) contribute in any way to brain tumor development? Is the $\mathrm{pRB} / \mathrm{p} 107-$ binding region a critical factor in brain tumor induction by the amino-terminal fragment? Is the tumorigenic activity of $d l 1137$ cell specific? These and other related issues are addressed in the following experiments.

\section{MATERIALS AND METHODS}

Plasmids. The construction of pLST and pLST1137 (carrying the LPV control region driving the wild-type and the amino-terminal SV40 T-antigen-coding regions, respectively) was previously described $(5,6)$. Plasmid pLST1137K1 (a hybrid between the LPV control region and the $1137 \mathrm{~K} 1$ coding region) is identical to pLST1137 except that it contains a single nucleotide change (C-4500 to $\mathrm{T}$ ). It was constructed from plasmids pLPVEN $(4,5)$ and p1137K1. Plasmid p1137K1 contains the $1137 \Delta t$ coding region in the pTZ-19U phagemid vector background. The point mutation resulting in a glutamic acid-to-lysine change of residue 107 was introduced by sitedirected mutagenesis, performed by using the phagemid system supplied by Bio-Rad. The full SV40 T-antigen-coding region (StuI-to-BamHI fragment) was cloned into the phagemid for mutagenesis. The $\mathrm{K} 1$ point mutation was introduced by using a primer of the following sequence: 5'TTG CTC AAA AGA AAT GCC AT3' (the G-to-A mutation is underlined). Conditions for mutagenesis and for phage and phagemid growth were as suggested by Bio-Rad. The EcoRI to Asp 718 fragment from pLPV-EN (containing the LPV region) was isolated and inserted into the EcoRI and Asp 718 sites of p1137K1 to generate pLST1137K1. The entire dl1137K1coding region was confirmed by sequence analysis of pLST $1137 \mathrm{~K} 1$.

Production and screening of transgenic mice. LST mice harbor the wild-type large-T-antigen-coding region under LPV transcriptional control and have been previously described (6). The fusion genes from both LST1137 and LST1137K1 were isolated after digestion of the corresponding plasmids with EcoRI and SalI. Fragment purification and the production and screening of transgenic mice were carried out as described previously $(4,32)$. The final DNA concentrations were adjusted to $4 \mu \mathrm{g} / \mathrm{ml}$. Single-cell embryos were obtained from a cross between B6D2F1 (C57B16/J × DBA2; The Jackson Laboratory) mice.

Antibodies. Monoclonal antibodies specific for SV40 T antigen, PAb419 (30) and PAb108 (26), have been described previously. The epitope recognized by PAb419 maps to the first 60 aa of SV40 T antigen, and that recognized by PAb108 maps to the first 100 aa. PAb421 is a monoclonal antibody directed against mouse p53. All monoclonal antibodies were prepared as tissue culture supernatants or further concentrated by using standard protein A-Sepharose columns (Pharmacia).

For the in situ detection of $d l 1137$ and $d l 1137 \mathrm{~K} 1$ proteins, specific antibodies were purified from a hamster polyclonal anti-large-T-antigen ascites (43). Antibody was first enriched by using protein A-Sepharose columns. Subsequently, $2 \mathrm{mg}$ of affinity-purified, baculovirus-encoded $d l 1137$ protein (a kind gift of J. Pipas) was diluted in $5 \mathrm{ml}$ of $20 \mathrm{mM}$ Tris-150 mM glycine ( $\mathrm{pH} 8.0)$ and spotted onto a nitrocellulose filter ( 1.5 by $3 \mathrm{~cm}$; Schleicher \& Schuell, Inc.). The filter was treated for 30 min with $3 \%$ bovine serum albumin (BSA)-5\% powdered milk in $10 \mathrm{mM}$ Tris- $\mathrm{HCl}(\mathrm{pH} \mathrm{8.0)}-150 \mathrm{mM} \mathrm{NaCl}-0.2 \%$ Tween 20 (TST) and then incubated for $1 \mathrm{~h}$ with $1 \mathrm{ml}$ of anti-SV40 T-antigen hamster ascites fluid diluted 1:2 in TST-3\% BSA-5\% powdered milk. After five 5-min washes with TST, bound antibody was eluted by incubating the filter in $1 \mathrm{ml}$ of $100 \mathrm{mM}$ glycine- $\mathrm{HCl}(\mathrm{pH} \mathrm{3.0)}$ for $60 \mathrm{~s}$. The eluate was neutralized by adding $1 / 10$ volume of $1 \mathrm{M}$ Tris- $\mathrm{HCl}(\mathrm{pH} \mathrm{8.0)}$. The filter was washed twice for 5 min each time with TST, and then blocking, absorption, and elution were repeated when necessary. All incubations were carried out at $25^{\circ} \mathrm{C}$. Eluates were supplemented with $10 \%$ normal horse serum (Vector) and stored in aliquots at $-20^{\circ} \mathrm{C}$.

Histology and immunohistochemistry. For routine histology, tissues were fixed with Bouin's fixative for $1 \mathrm{~h}$ and embedded with paraffin. Five-micrometer sections were stained with hematoxylin and eosin (37). Tissues used for immunohistochemistry were frozen in liquid nitrogen and stored at $-80^{\circ} \mathrm{C}$. Eight-micrometer sections were prepared by using a cryostat at $-20^{\circ} \mathrm{C}$, on positively charged slides (ProbeOn; FisherBiotech), fixed in $2 \%$ formaldehyde in TS buffer ( 50 $\mathrm{mM}$ Tris- $\mathrm{HCl}$ [pH 7.6], $150 \mathrm{mM} \mathrm{NaCl}$ ) for $2 \mathrm{~min}$, washed twice with TS buffer, dehydrated in ethanol for $10 \mathrm{~min}$ at $4^{\circ} \mathrm{C}$, and transferred to TS buffer containing $0.2 \%$ Nonidet P-40 (NP40) for $5 \mathrm{~min}$ at $4^{\circ} \mathrm{C}$. After three washes with TS buffer, the sections were incubated with primary antibody (protein A-purified hamster polyclonal antibody specific to SV40 T antigen, prepared as described above) for $1.5 \mathrm{~h}$. After three washes with TS buffer and incubation for $1 \mathrm{~h}$ with secondary antibody (biotinylated goat anti-hamster immunoglobulin G; Pierce), the sections were stained by the Vectastain ABC method as specified by Vector Laboratories. Immune complexes were detected by incubation with horseradish peroxidase-avidin complex (Vector) and diaminobenzidine substrate. Dilution of antibodies was in TS buffer supplemented with $10 \%$ normal 
goat serum (Vector). All steps were performed at $25^{\circ} \mathrm{C}$ unless specified.

Immunodetection of S-phase cells. S-phase cells in tissue sections were detected by using the cell proliferation kit from Amersham, with minor modifications. Mice were injected intraperitoneally with 5-bromo-2'-deoxyuridine (BrdU; 0.01 $\mathrm{ml} / \mathrm{g}$ ) and sacrificed after $2 \mathrm{~h}$. Brains were dissected and processed as described above for immunohistochemistry. After the initial TS buffer washes, the sections were incubated for 1 $h$ with $10 \%$ normal goat serum (Vector) and then transferred to nuclease-anti-BrdU as suggested for an additional hour. Following three additional washes in TS buffer and incubation for $1 \mathrm{~h}$ with antimouse immunoglobulin G2a-peroxidase, the samples were stained with diaminobenzidine as the substrate. All steps were performed at $25^{\circ} \mathrm{C}$. After brief counterstaining with eosin $(0.25 \%, 2 \mathrm{~min})$, the sections were washed with distilled $\mathrm{H}_{2} \mathrm{O}$, dehydrated with $70 \%$ ethanol, and mounted for analysis.

Immunoprecipitation and immunoblotting analysis. Tissues were stored frozen at $-80^{\circ} \mathrm{C}$ prior to analysis. Samples (about $0.2 \mathrm{~g}$ ) were suspended in $2 \mathrm{ml}$ of lysis buffer containing $50 \mathrm{mM}$ Tris (pH 8.0), $5 \mathrm{mM}$ EDTA, $150 \mathrm{mM} \mathrm{NaCl}$, and $0.5 \% \mathrm{NP}-40$. Protease inhibitors phenylmethylsulfonyl fluoride $(25 \mathrm{mg} / \mathrm{ml})$, leupeptin $(0.5 \mathrm{mg} / \mathrm{ml})$, and pepstatin $(0.7 \mathrm{mg} / \mathrm{ml})$ were included in the lysis buffer (Boehringer Mannheim Biochemicals). Tissues were homogenized and sonicated for $10 \mathrm{~s}$ on ice. The tissue extracts were cleared twice by centrifugation at 735 $\times g$ for 10 to $15 \mathrm{~min}$. Protein determinations, immunoprecipitation reactions, and polyacrylamide denaturing gel electrophoresis were performed as described previously (72).

Proteins were transferred to nitrocellulose (Bio-Rad) for $7 \mathrm{~h}$ to overnight at $25 \mathrm{~V}$ in $20 \mathrm{mM}$ Tris-150 mM glycine-20\% methanol. Filters were air dried, rinsed in TBS-NP-40 $(0.2 \mathrm{M}$ $\mathrm{NaCl}, 50 \mathrm{mM}$ Tris-Cl [pH 7.4], 0.1\% NP-40), and blocked with $3 \%$ BSA and 5\% dry milk powder in TBS-NP-40 for $1 \mathrm{~h}$. Filters were incubated for $1 \mathrm{~h}$ at room temperature with monoclonal supernatants or an appropriate primary antibody dilution. The optimal antibody concentrations were estimated by testing serial dilutions for their capacity to detect purified standard amounts of $d l 1137$ protein spotted into nitrocellulose paper. Following each antibody incubation, filters were washed three times with TBS-NP-40. The filters were then incubated for $1 \mathrm{~h}$ at room temperature with a 1:3,000 dilution of protein A-conjugated horseradish peroxidase (Zymed). All antibodies were diluted in TBS-NP-40 supplemented with 3\% BSA and $5 \%$ dry milk powder. Following incubation, the filters were rinsed as described above. Specific reactions were detected as recommended, using the ECL (enhanced chemiluminescence) system (Amersham).

\section{RESULTS}

T-antigen amino-terminal fragment induces a cell-specific response in transgenic mice. To fully characterize the role of $d l 1137$ in choroid plexus tumorigenesis and to determine its effect in the lymphoid system, seven additional LST1137 founder mice and two independent families of mice were generated for analysis. The LST1137 transgene encodes the dl1137 protein under control of the LPV transcriptional signals (Fig. 1A; see the introduction). In transgenic mice, this regulatory region consistently directs expression to the $\mathrm{B}$ and $\mathrm{T}$ lymphocytes and to the CPE $(4,6)$. The LST1137 transgene does not encode small $t$ antigen as a result of removal of the small t-specific splice donor site (see Materials and Methods). The T antigen expressed by LST1137 is truncated after residue 121 as a result of a small out-of-frame deletion which also results in the addition of 11 missense residues $(61,70)$. This form of $\mathrm{T}$ antigen binds pRB (70a) but lacks the p53-binding region (Fig. 1B). Moreover, although $T$ antigen normally stabilizes p53 (46), $d l 1137$ does not (60a).

Of nine founder mice generated with the LST1137 transgene in a previous study, four mice developed an abnormally enlarged choroid plexus leading to hydrocephaly in two mice and overt tumors in two mice (5) (Table 1, LST1137-1 through $-4)$. Of the additional seven founder mice produced in this study, four mice developed choroid plexus tumors (Table 1, LST1137-5 through -8). Extensive expansion of the choroid plexus, often accompanied by hydrocephaly, was observed in these mice (Table 1). As in our preliminary studies with $d l 1137$, the tumors became life threatening much later than did those induced by wild-type $T$ antigen (averaging 30 weeks, compared with 9 weeks with wild-type T antigen; Fig. 2A). No abnormal phenotype was consistently observed in any other tissue of these mice, including spleen and thymus.

Two founder mice that developed representative choroid plexus tumors (LST1137-5 and -6) were used to establish independent families of LST1137 mice for further analyses. All transgenic mice in both lineages reproducibly developed CPE tumors, reaching a life-threatening stage at an average of 6 to 7 months of age (Fig. 2B and Table 1). The fact that the phenotype was $100 \%$ penetrant in the LST1137-5 and -6 lineages (Fig. 2B) suggests that the lower frequency of tumor development in the LST1137 founder mice (50\%, compared with $75 \%$ with wild-type T antigen; Fig. $2 \mathrm{~A}$ ) most likely reflects the influence of some insertion sites on transgene expression (59) rather than the requirement for additional stochastic events for tumorigenesis. In previous studies with $d l 1137$ and with other mutants of $T$ antigen, the founder mice that did not develop a phenotype did not express the protein $(5,73)$. Further characterization of brain tumor progression (described below) supports this explanation.

Lymphoid abnormalities were not detected in LST1137 founder mice or in LST1137-5 or LST1137-6 transgenic offspring. Histological analysis showed spleens and thymuses to be normal (data not shown). This result is in contrast with those for mice harboring wild-type $\mathrm{T}$ antigen, which develop both $\mathrm{B}$ - and T-cell abnormalities (6), and mice harboring another mutant of $\mathrm{T}$ antigen ( $d l 1135)$, which consistently develop T-cell lymphoma (see Discussion and reference 73). Fluorescence-activated cell sorting (FACS) analysis of thymocytes from LST1137 animals (2 to 4 months of age) also demonstrated a normal subset distribution (data not shown), unlike mice of the same age undergoing T-antigen-induced thymoma, which show a distinctly abnormal T-cell distribution (73). In an even more sensitive assay, thymocytes from LST1137 mice underwent normal irradiation-induced apoptosis, a pathway that is disrupted by a T-antigen variant that consistently induces T-cell lymphoma (56).

dl1137 is sufficient to induce abnormal growth of the choroid plexus. The reproducible age at which full CPE expansion occurred in mice from both LST1137-5 and -6 lines suggested that only the amino-terminal 121 residues of $T$ antigen were required to induce the tumorigenic process in this cell type. On the other hand, as was observed with LST1137 founder mice, development of the phenotype was delayed considerably in comparison with that induced by wild-type $\mathrm{T}$ antigen (compare LST in Fig. 2A with Fig. 2B). To determine whether this reflected the requirement for secondary somatic events, which should lead to focal growth of tumors, we characterized the morphological progression of abnormal changes in the CPE of LST1137 mice from each family.

Figure 3 shows the representative morphology of the cho- 


\section{A}
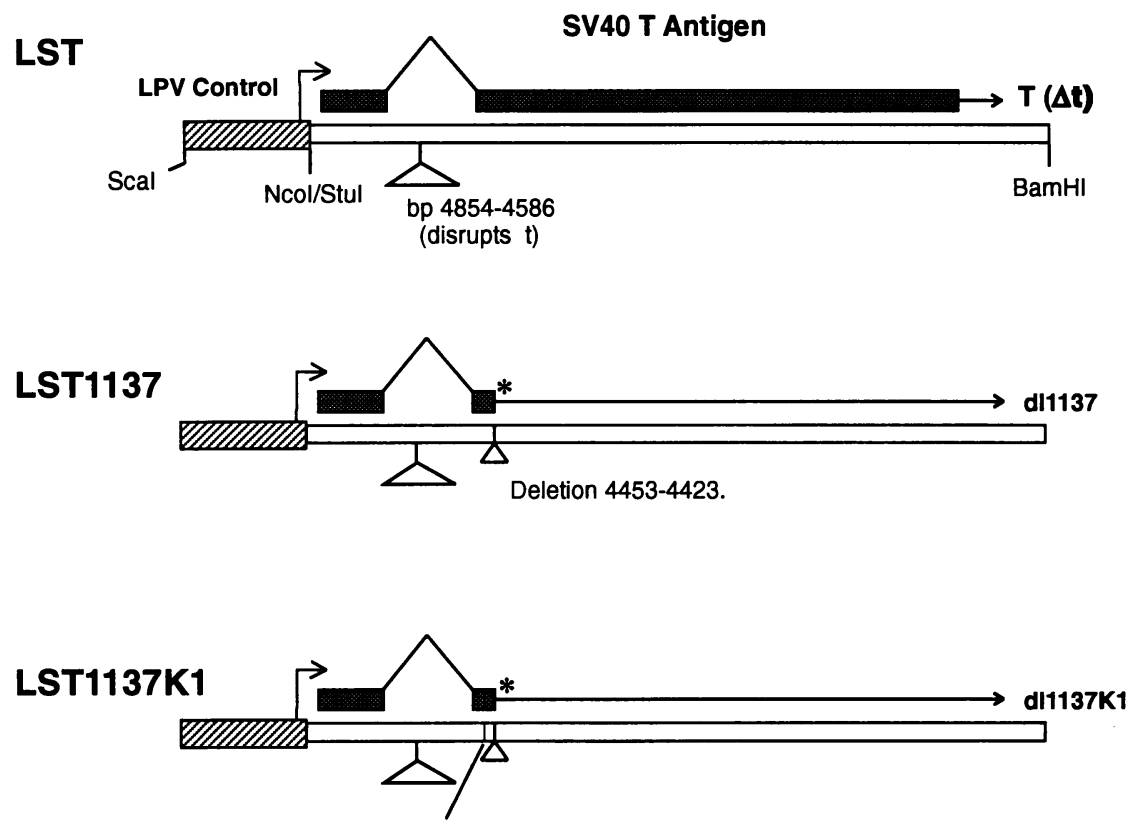

bp 4500: $\mathrm{C}$ to $\mathrm{T}$

B

wild type

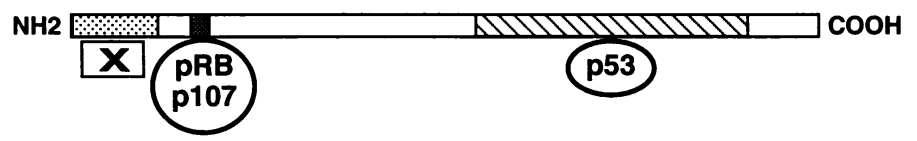

dl1137

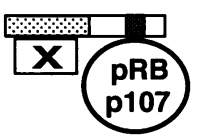

dl1137K1

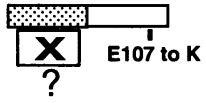

FIG. 1. Diagrams of the LST1137 and LST1137K1 transgenes (A) and their encoded proteins (B). The ScaI-to-BamHI fragment containing the respective LST fusion gene was used for the generation of transgenic mice. The fragment consists of the 580-bp LPV control region ( the mutant SV40 T-antigen-coding region ( $\square$ ). In panel A, shaded boxes represent exons. Linear diagrams of wild-type, $d l 1137$, and $d l 1137 \mathrm{~K} 1$ $\mathrm{T}$ antigens are shown in panel $\mathrm{B}$. Regions involved in binding pRB, p107, and p53 are indicated. X indicates a genetically defined transforming activity whose corresponding biochemical function(s) has not been identified (73). Both $d l 1137$ and $d l 1137 \mathrm{~K} 1$ proteins encode the amino-terminal region of $\mathrm{T}$ antigen (121 residues) followed by 11 missense amino acids $(*)$. dl1137K1 further contains a single amino acid change $(\mathrm{E}-107 \rightarrow \mathrm{L})$ in the pRB/p107 region. Both transgenes harbor a deletion of SV40 (from nucleotides 4854 to 4586 ) that disrupts the expression of small $t$ antigen as a result of removal of the small t-specific splice donor site (10). This mutation does not affect the expression of large $\mathrm{T}$ antigen since it lies entirely within the large $T$ intron. 
TABLE 1. Phenotypes of LST1137 and LST1137K1 transgenic mice ${ }^{a}$

\begin{tabular}{llc}
\hline \multicolumn{1}{c}{ Mouse or line } & Phenotype & $\begin{array}{c}\text { Age (wk) at } \\
\text { death }\end{array}$ \\
\hline Transgenic founder mice & & \\
LST1137-1(b) & HC & 11 \\
LST1137-2 & HC & 19 \\
LST1137-3 & CPT & 24 \\
LST1137-4 & CPT & 34 \\
LST1137-5 & CPT & 26 \\
LST1137-6 & CPT & 29 \\
LST1137-7 & CPT & 34 \\
LST1137-8 & CPT & 42 \\
LST1137-9-16 & Normal & \\
LST1137K1-1 & ND & $>52$ \\
LST1137K1-2 & ND & 17 \\
LST1137K1-3-31 & Normal & \\
& & \\
Transgenic lines & & $14-44(45 / 45)$ \\
LST1137-5 & CPT & $12-36(11 / 11)$ \\
LST1137-6 & CPT & $>37(16 / 16)$ \\
LST1137K1-3 & Normal & $>36(11 / 11)$ \\
LST1137K1-4 & Normal & $>38(10 / 10)$ \\
LST1137K1-5 & Normal \\
\hline
\end{tabular}

${ }^{a}$ Pathological changes were observed during dissection and confirmed by histological examinations. Mice indicated as normal were macroscopically nor$\mathrm{mal}$ at the time of sacrifice. Brain-related phenotypes are indicated as CPT (choroid plexus tumor) and HC (hydrocephaly). Animals were sacrificed when abnormalities were grossly apparent or near the end of the study. The LST1137-1 to -4 and LST1137-9 to -13 founder mice were described previously (5). Four of the 29 LST1137K1 founder mice listed as normal died near 1 year of age with no detectable abnormalities. Another apparently normal mouse (LST1137K1-2) died of unknown causes at 17 weeks. A final LST1137K1 mouse which appeared normal (LST1137K1-2) was sacrificed near the end of the study and found to have a growth under the right forelimb which was not analyzed further. None of the LST1137K1 founder mice had detectable abnormalities in the choroid plexus. All animals of lines LST1137K1-3, -4, and -5 sacrificed near the age indicated were found to be phenotypically normal. These mice spanned generations 1 to 4,1 to 6 , and 1 to 3 , respectively. ND, not determined.

roid plexus at the earliest ( 1 month after birth) and at one of the latest ( 7 months) times examined; several more mice at ages 1 to 9 months were also examined. Transgenic mice of both LST1137-5 and LST1137-6 families consistently showed abnormal morphology of the choroid plexus. By 1 month of age, most epithelial cells in the choroid plexus appeared crowded and highly abnormal, with reduced cytoplasm and darkly stained nuclei sometimes of variable size (Fig. 3; compare normal CPE in panel a with LST1137 CPE in panel b). Usually at this early stage, the overall tissue organization was retained and patchy areas of more normal-appearing cells were often present (Fig. 3b). As the animals aged, the fourth and two lateral ventricles of the brain continued the same pattern of general expansion and morphological abnormalities became more severe. Numerous giant and aberrantly shaped nuclei were present, and the characteristic single-cell layer organization was perturbed (Fig. 3c). Although the choroid plexus of the third ventricle was clearly morphologically altered, it did not appear to increase in size to the same extent, perhaps because of the limited amount of tissue normally present in this region of the brain (69). By 7 months of age, the three ventricles were distended and filled with highly abnormal anaplastic cells as had been observed with wild-type $T$ antigen at a much earlier age (6). Examination of several time points showed no evidence of focal tumor growth that would indicate the participation of secondary somatic mutations in tumor induction.

dl1137 induces abnormal epithelial cell proliferation. In a

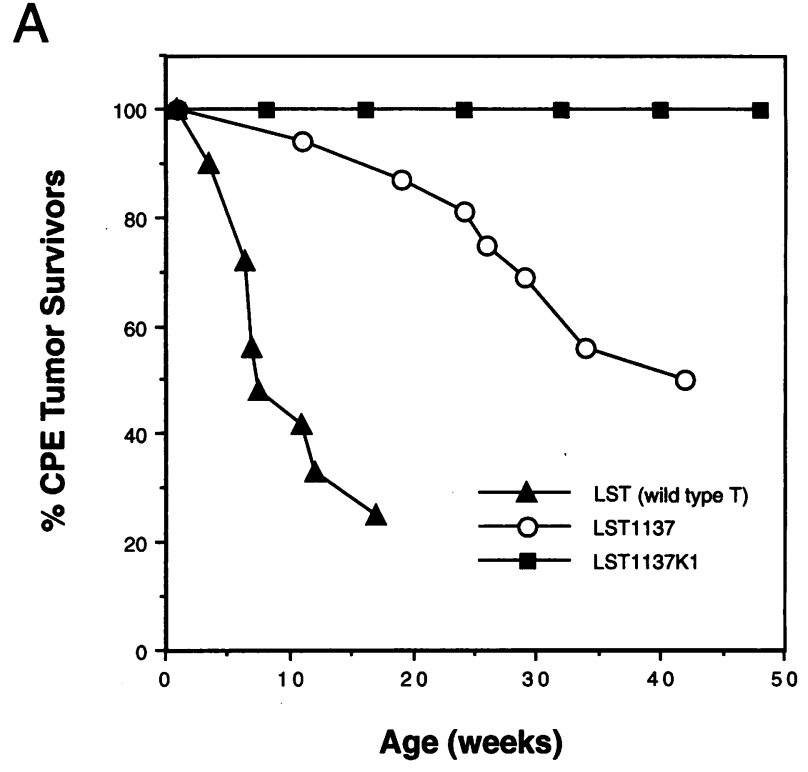

B

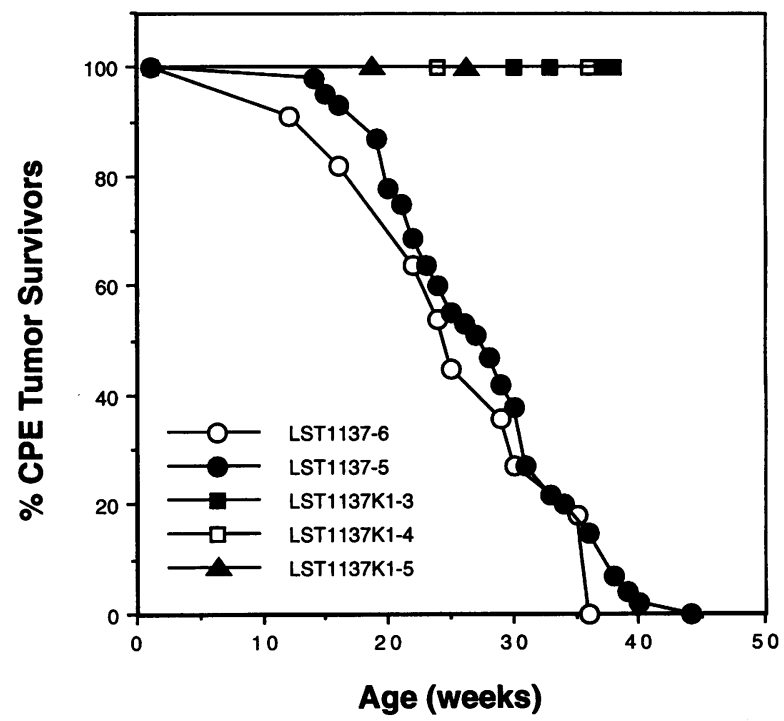

FIG. 2. Survival of LST, LST1137, and LST1137K1 transgenic mice. Survival of founder mice is shown in panel A, and survival of mice in the transgenic lineages LST1137-5 and -6 and LST1137K1-3, -4 , and -5 is shown in panel B. Mice born in several different litters after the $F_{1}$ generation were included in the survival curves. Animals were sacrificed for analysis when death appeared imminent or after 12 months of age. The age of sacrifice versus the percentage of animals surviving choroid plexus abnormalities was plotted. Mice determined to be normal and sacrificed at 12 months are registered as survivors. LST founder mice graphed in panel A express wild-type T antigen and are described in reference 6 . See Table 1 for further information on each founder mouse that developed an abnormal phenotype.

normal mouse, there is a dramatic decrease in CPE cell proliferation by birth and then complete cessation within the first 2 weeks of life (52). In response to wild-type $T$ antigen, the entire choroid plexus remains proliferative throughout the short life of the animal, with approximately $30 \%$ of the cells in 

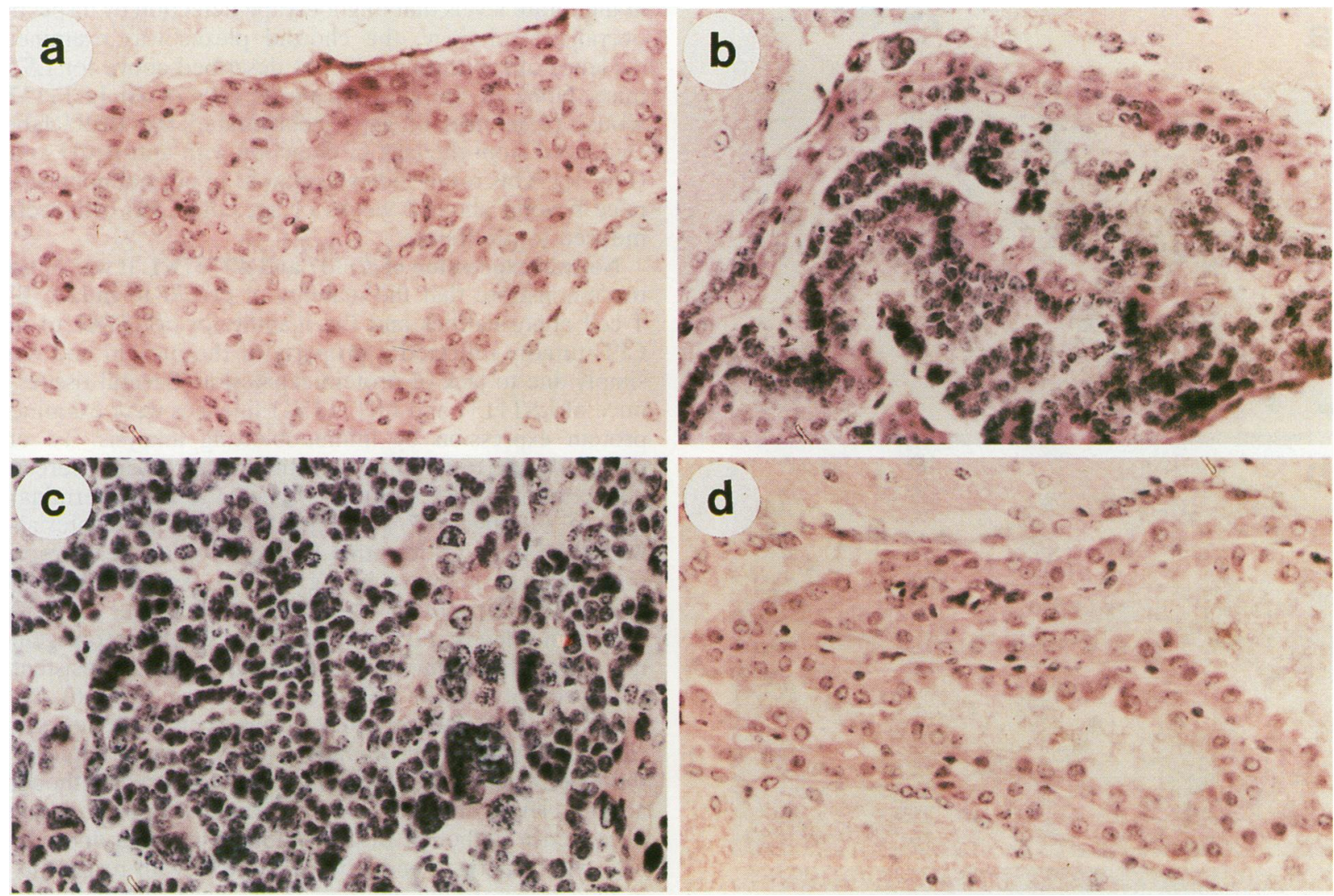

FIG. 3. Choroid plexus morphology in LST1137 and LST1137K1 transgenic mice. Brain sections were stained with hemotoxylin and eosin. Shown is a representative lateral ventricle choroid plexus from a 5-month-old nontransgenic mouse (a), 1-month-old (b) and 7-month-old (c) LST1137-6 mice, and a 5-month-old LST1137K1-5 transgenic mouse (d).

$S$ phase at any given time (6). Another possible reason for later appearance of tumors induced by $d l 1137$ was that although cells were morphologically altered at a very early age, they did not proliferate until secondary epigenetic changes occurred in the animal. To determine whether cells were in fact progressing through the cell cycle at early ages, we measured the percentage of cells in $S$ phase after BrdU incorporation in vivo (Fig. 4). Cells undergoing DNA synthesis during the 2-h labeling time were detected by using an antibody specific for BrdU (see Materials and Methods). At 3 weeks of age, when cells in $\mathrm{S}$ phase cannot be detected in normal choroid plexus $(6,52)$ (identical to Fig. 4c), approximately $30 \%$ of the cells in LST1137 choroid plexus were in S phase (Fig. 4a). This number remained constant at later ages (4 months) when the choroid plexus had clearly expanded (Fig. 4b). At each point examined, the distribution of S-phase cells appeared random, not focal, indicating uniform widespread abnormality, as morphological examination had also suggested. These results indicate that the amino-terminal 121-aa fragment of $\mathrm{T}$ antigen is sufficient to induce abnormal cell proliferation, morphological alteration, and expansion of the CPE comparable to that induced by wild-type $\mathrm{T}$ antigen. Hence, the critical difference in CPE tumors induced by wild-type and $d l 1137 \mathrm{~T}$ antigens is the overall rate of tumor growth. Possible mechanisms for a decreased tumor growth rate in LST1137 mice are explored in Discussion.

The $\mathrm{pRB} / \mathrm{p} 107-b i n d i n g$ region is critical for brain tumor induction. Genetic studies in cultured cells have indicated that the $\mathrm{pRB} / \mathrm{p} 107-\mathrm{binding}$ region of $\mathrm{T}$ antigen is important for transformation (see the introduction). Our preliminary work in transgenic mice also indirectly implicated a role for this activity(ies) in the induction of brain tumors (5). To further test this hypothesis, we introduced into the LST1137 transgene a single-base change ( $\mathrm{C}-4500$ to $\mathrm{T})$ that results in a glutamic acid-to-lysine mutation in the $\mathrm{pRB} / \mathrm{p} 107$-binding region (aa 107). This alteration (35) has been shown to disrupt binding of $\mathrm{T}$ antigen to both $\mathrm{pRB}$ and $\mathrm{p} 107(13,21)$. The resulting gene (LST1137K1), also under the control of the LPV transcriptional signals (Fig. 1), was used to generate 31 transgenic founder mice.

None of the LST1137K1 founder mice developed choroid plexus abnormalities (Table 1). In fact, all but one mouse survived to old age (Table 1). For more rigorous analyses, three independent lines were generated from the LST1137 $\mathrm{K} 1-3,-4$, and -5 founder mice (Table 1 and Fig. 2B). Mice of these lineages, like the majority of LST1137K1 founder mice, had a normal phenotype. One animal in each line died of unknown causes, although neither of them presented signs of brain abnormalities (not shown). The remaining LST1137K1 transgenic animals which were not sacrificed for analysis (37 mice in all) survived to more than 8 months of age (Fig. 2B and Table 1). The brains of four mice of different ages between 1 and 9 months were analyzed histologically for signs of abnormality in the CPE. As with the founder LST1137K1 mice, no abnormalities were detectable. A representative brain section is shown in Fig. 3d. In contrast to the CPE of LST1137 mice (Fig. 3b and c), where the cell morphology was highly aberrant and the amount of tissue excessive, the CPE of LST1137K1 

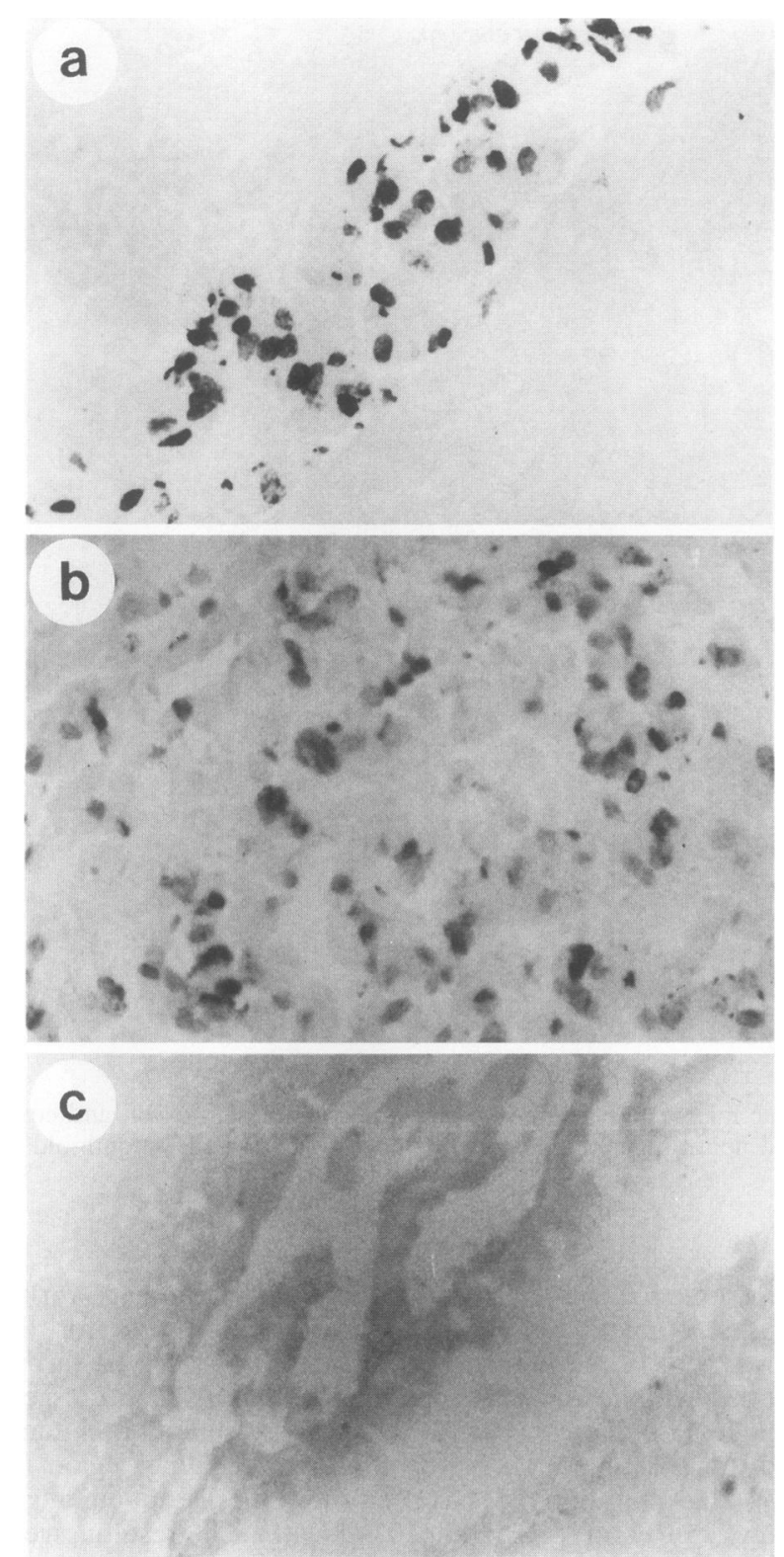

FIG. 4. Proliferation of choroid plexus cells in transgenic mice. Mice were treated with BrdU for $2 \mathrm{~h}$ before sacrifice, when brains were frozen and sectioned as described in Materials and Methods. Cells which had incorporated the label were detected after immunoperoxidase staining with an antibody specific for BrdU. Shown are representative fields from a 3-week-old LST1137-5 transgenic mouse (a), a 4-month-old LST1137-6 transgenic mouse (b), and an 8-month-old LST1137K1-5 transgenic mouse (c). In LST1137 mice of both ages, approximately $30 \%$ of the choroid plexus cells were positive for the BrdU signal. None of the cells examined from the LST1137K1 mice or from nontransgenic age-matched controls (not shown) showed evidence of BrdU incorporation.

animals of all ages was indistinguishable from that of normal nontransgenic mice (compare panels Fig. 3a and d). Cells retained the characteristic cuboidal morphology having regularly shaped, uniformly stained nuclei and clearly detectable cytoplasm. The normal papillary structure of the tissue was also present.

To determine whether $d l 1137 \mathrm{~K} 1$ induced cell proliferation at moderate levels that might escape detection by inspection of overall morphology, the choroid plexus was examined for evidence of replicating DNA as described above for LST1137 mice. None of the choroid plexus cells of an LST1137K1-5 mouse ( 8 months of age) incorporated the BrdU label, as evidenced from the lack of detection with anti-BrdU antibody (Fig. 4c). This result indicates that as in normal nontransgenic mice beyond about 2 weeks of age, the CPE cells were not induced to proliferate.

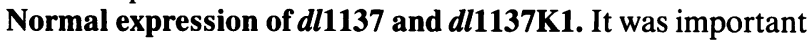
to demonstrate that the inability of $d l 1137$ to induce B- and T-cell abnormalities and the inability of $d l 1137 \mathrm{~K} 1$ to induce CPE tumors reflected a property of the protein and was not simply due to lack of protein expression. Several tissues from mice of LST1137 and LST1137K1 lineages were examined for protein expression by immunoblotting analysis. To ensure specificity and to optimize sensitivity, the proteins were immunoprecipitated with antibodies specific to the N-terminal portion of T antigen (PAb108 and PAb419; see Materials and Methods) prior to detection by immunoblotting. A representative analysis is shown in Fig. 5A. As expected, both $d l 1137$ and $d l 1137 \mathrm{~K} 1$ proteins were expressed in brains (Fig. 5A and C) and in spleens and thymuses (Fig. 5B) of the transgenic but not the nontransgenic control animals, a result consistent with the specificity of the LPV regulatory region (4-6). Neither protein was detected in other tissues, such as kidney and liver (data not shown). The $\mathrm{T}$-antigen variants were detected with this specificity in all transgenic lines analyzed, although the absolute levels differed for each particular tissue and line (Fig. 5B). Hence, although the two mutant proteins differed from wild-type $T$ antigen and from each other with respect to their in vivo transforming abilities, their expression patterns were the same. Furthermore, immunoprecipitation with an anti-p53 monoclonal antibody prior to immunoblotting confirmed that neither $d l 1137$ nor $d l 1137 \mathrm{~K} 1$ associates with p53 in tissues (Fig. 5A, lanes 4 and 8 ).

Although $d l 1137 \mathrm{~K} 1$ was detected in brain despite of the lack of abnormality, a formal possibility was that the level of expression was significantly lower than that at which $d l 1137$ disrupts the growth of CPE cells. To determine whether this was the case, protein expression was compared between LST1137-5 mice (which consistently developed CPE tumors) and LST1137K1-5 mice (which never developed abnormalities). Since the CPE tissue of LST1137 mice expanded with age, the brains of several young mice were examined in order to compare levels of protein when a comparable amount of CPE tissue was present. Although less informative, the level of protein in total brain at later times was also assessed. During the time prior to massive CPE expansion in LST1137 mice (1 to 3 months), comparable levels of the two proteins were detected (Fig. 5C). During this 1- to 3-month age period, however, the $d l 1137$-expressing cells were morphologically altered (Fig. 3b) and were clearly proliferating abnormally (Fig. 4a), while the $d l 1137 \mathrm{~K} 1$-expressing cells remained normal throughout the animal's life span (Fig. 3d and 4c). As anticipated, the amount of $d l 1137$ protein present in total brain increased subsequently with age (4 to 10 months; Fig. $5 \mathrm{C}$ ), in correlation with the observed increase in the total amount of choroid plexus tissue (Fig. 3c). In contrast, the constant amount of CPE in total LST1137K1 brain at all times yielded a constant level of $d l 1137 \mathrm{~K} 1$ protein (Fig. 5C).

In both cases, the $\mathrm{T}$-antigen variants detected in brain were localized to the choroid plexus, as evidenced from in situ immunodetection using affinity-purified $\mathrm{T}$-antigen-specific antibodies (Fig. 6). As expected from the small size and lack of nuclear localization signal in these mutant proteins, the signals 

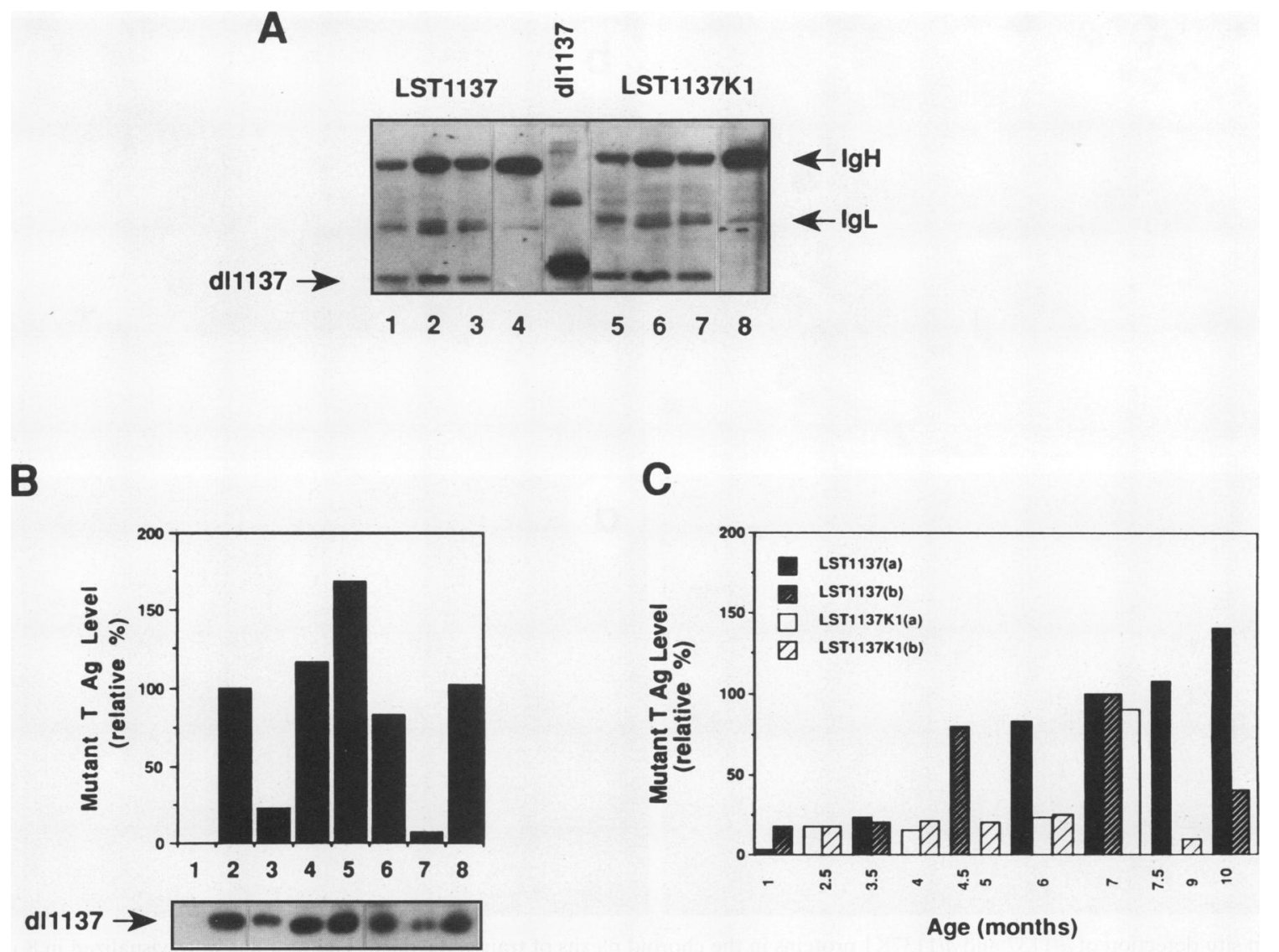

FIG. 5. Expression of $d l 1137$ and $d l 1137 \mathrm{~K} 1$ proteins in transgenic mice. In panel A, the truncated T-antigen proteins in brain extracts of LST1137-5 (15-week-old) and LST1137K1-5 (18-week-old) animals were detected by immunoblotting with an antibody specific for the amino terminus of T antigen (PAb108). Specific proteins were immunoprecipitated prior to immunoblotting with polyclonal hamster anti-T-antigen antibody (lanes 1 and 5), anti-T-antigen monoclonal antibodies (PAb108 [lanes 2 and 6] and PAb419 [lanes 3 and 7]), or an anti-p53 antibody (PAb421 [lanes 4 and 8]). The positions of heavy and light immunoglobulin subunits (IgH and IgL) are indicated. Purified baculovirus-produced dl1137 protein served as a marker (middle lane; higher-molecular-weight forms present in this lane are most likely undenatured multimers of $d l 1137)$. In panel $\mathrm{B}$, the relative amount of each mutant $\mathrm{T}$-antigen (TAg) protein in spleens and thymuses was determined. The $d l 1137$ and $d l 1137 \mathrm{~K} 1$ proteins were immunoprecipitated from $300 \mathrm{mg}$ of total protein with polyclonal hamster anti-T-antigen antibody and detected by immunoblotting as in panel A. The level of signal relative to that obtained from brain extract of a 5-month-old LST1137-6 transgenic mouse (lane 2) was determined by densitometric analysis. The bands and quantified signals correspond to the following samples: nontransgenic brain (4 month, lane 1), LST1137-6 brain (5 month, lane 2); LST1137-6 spleen (5 month, lane 3), LST1137K1-3 spleen (4 month old, lane 4; 1 year old, lane 5), LST1137-6 thymus (5 month, lane 6), and LST1137K1-3 thymus (4 month, lane 7; 1 year, line 8). In panel C, the levels of $d l 1137$ and $d l 1137 \mathrm{~K} 1$ proteins in brain tissue of mice at various ages were determined as described for panel B. Each bar represents the total amount of the T-antigen ( $\mathrm{T} \mathrm{Ag}$ ) protein present in an individual brain arbitrarily compared with the amount present in a LST1137 7-month-old brain. LST1137-5 samples are indicated with dark bars, and LST1137K1-5 samples are indicated with lighter bars. Two data sets (a and b) are shown. The values within a set were determined in the same experiment. Two samples (from one 7-month-old LST1137K1 and one 10-month-old LST1137 mouse) showed unusual protein levels which were not reproduced in further analysis of the same lines (data not shown).

were present in both the nuclei and cytoplasm. Cells throughout the choroid plexus of LST1137K1 mice stained uniformly, indicating consistent levels of protein in most cells (Fig. 6b). Most cells of the LST1137 choroid plexus also showed a similar pattern of staining, although the cell morphology was abnormal (Fig. 6a). Within the LST1137 choroid plexus, a small number of intensely stained cells with dense nuclei were detected. Since similar cells were not observed in $d l 1137 \mathrm{~K} 1-$ expressing tissue, the presence of these cells may reflect the actively growing status of the LST1137 choroid plexus. Further experiments will be required to determine the significance of this observation. Overall, although we cannot exclude the possibility that subtle differences in protein levels exist between LST1137 and LST1137K1 mice, the in situ and immunoblotting analyses of mutant $\mathrm{T}$-antigen protein expression strongly support the hypothesis that the induction of CPE tumors by the $d l 1137 \mathrm{~T}$ antigen is dependent on the presence of an intact domain of interaction with pRB and p107.

\section{DISCUSSION}

We have used the SV40 T antigen in transgenic mice as a tool to determine the functions of its cellular targets and their roles in tumorigenesis of different cell types. In this study, we examined the tumorigenic capacity of a $\mathrm{T}$-antigen fragment that contains only the amino-terminal 121 aa and thus has no ability to interact with p53 but retains the pRB/p107-binding region. This fragment induces tumors in a cell-specific fashion; i.e., the truncated $T$ antigen is sufficient to induce choroid plexus tumors but is unable to detectably disrupt cell growth 

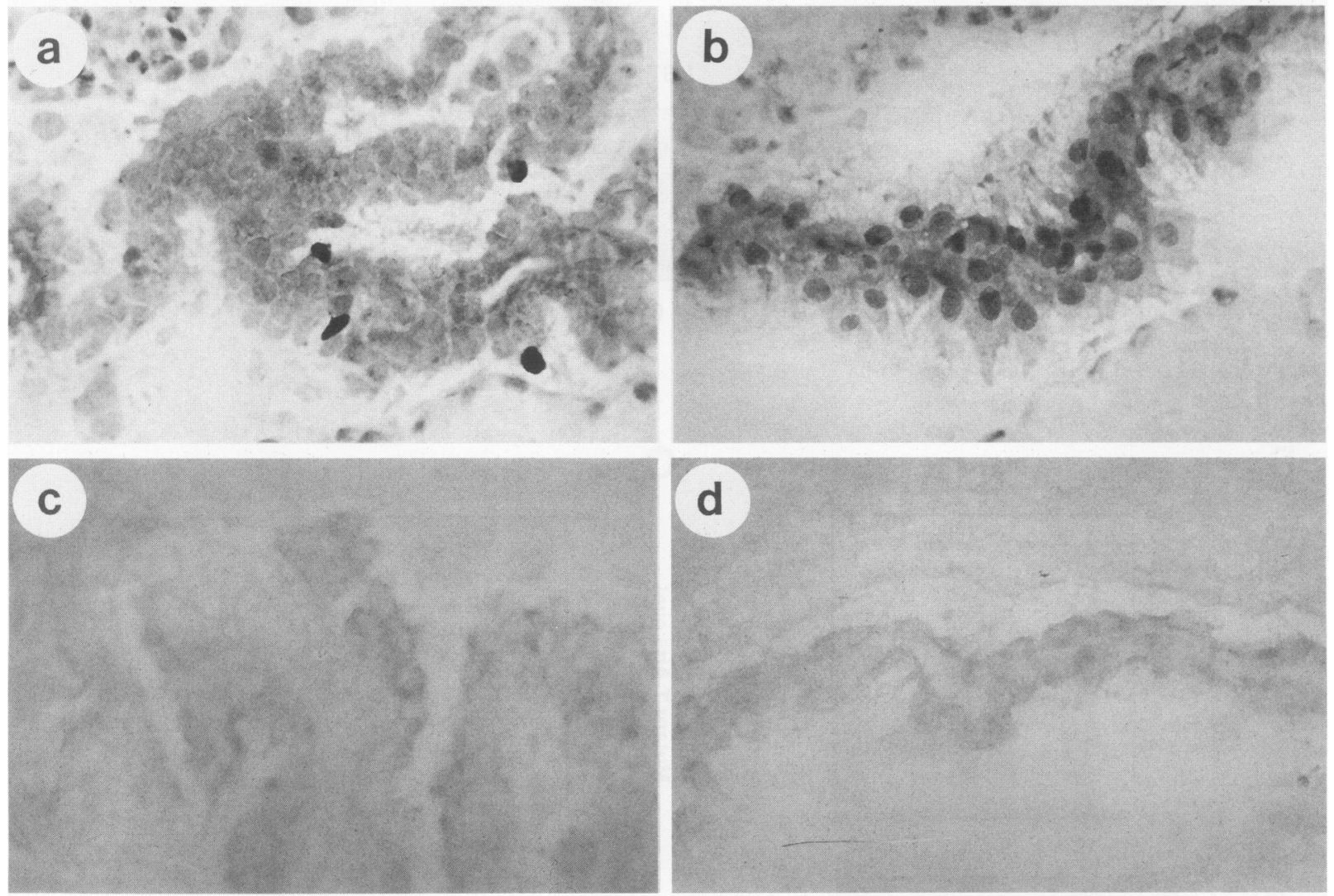

FIG. 6. In situ detection of $d l 1137$ and $d l 1137 \mathrm{~K} 1$ proteins in the choroid plexus of transgenic mice. The proteins were visualized in 8 - $\mu \mathrm{m}$ brain sections from a 3-week-old LST1137-5 mouse (a and c) and a 7.5-month-old LST1137K1-5 mouse (b and d) by indirect immunohistochemistry (Materials and Methods), using an affinity-purified polyclonal hamster anti-T-antigen antibody (a and b). No signal was detected in the absence of specific primary antibody treatment (c and $d)$.

regulation in either B or T lymphoid cells. These observations confirm and extend our previous analysis of $T$ antigen variants in transgenic mice (see below), indicating that the relative contribution of $\mathrm{T}$-antigen activities to tumorigenesis differ according to the cell type and/or developmental stage. This differential effect may reflect the use of different pathways for growth regulation in each cell type or different requirements for the establishment of abnormal tumor growth. In addition, the cellular targets of $\mathrm{T}$ antigen may simply have different functions depending on the cell type, stage of differentiation, or cellular environment. The possible role of T-antigen functions in each cell type examined is discussed below.

Role of pRB/p107 binding in brain tumor induction. To determine the critical activities involved in brain tumor induction present within the amino-terminal 121 aa of $T$ antigen, we directed a mutation (35) to a position that was shown previously to disrupt the $\mathrm{pRB} / \mathrm{p} 107$-binding function of wild-type $\mathrm{T}$ antigen $(13,21)$. The resulting $d l 1137 \mathrm{~K} 1$ mutant was unable to induce choroid plexus tumors, suggesting that interaction of $\mathrm{T}$ antigen with pRB and/or p107 is essential to alter normal growth of the CPE. The inability of $d l 1137 \mathrm{~K} 1$ to induce CPE abnormalities could not be explained by lower levels of protein expression, as it was consistently and specifically expressed in the choroid plexus at levels comparable to levels of $d l 1137$ expression (Fig. 5 and 6). From the current studies, we cannot determine whether the critical function disrupted in $d l 1137 \mathrm{~K} 1$ is the interaction with $\mathrm{pRB}$ or p107 or both. Moreover, this mutation could change the protein conformation and disrupt other activities in the amino terminus for which there is as yet no biochemical assay (such as the activity known to reside within the first $82 \mathrm{aa}$ ). Our studies would suggest, however, that the interaction of one host protein, p185, with $d l 1137$ is not sufficient for tumor induction, since this interaction was previously shown to be undisturbed by the K1 mutation (39). Whether this and other amino-terminal T-antigen activities play a role in tumor induction will require more extensive analysis of the T-antigen amino-terminal fragment in transgenic mice.

The absence of abnormal cell division in the CPE of LST1137K1 mice compared with LST1137 mice suggests that the $\mathrm{pRB} / \mathrm{p} 107$-binding function may either prevent cessation of cell proliferation during CPE differentiation or inappropriately initiate cell division after differentiation. Indeed, experiments in cultured cells have shown that several properties of $\mathrm{pRB}$ are consistent with a general role in cell cycle regulation $(3,7,14$, $18,22,25,31$; for reviews, see references 11,27 , and 58), and recent reports suggest a similar function for p107 (84). However, the observed abnormalities in mice homozygous for a null mutation in the $R b$ locus are limited and specific $(8,34,44)$. Arrested embryos (around embryonic days 12 to 14) show abnormalities in the central nervous system, including the presence of mitotic cells in nonmitotic zones and increased cell death. The embryos also show signs of impaired hepatic erythropoiesis, evidenced from the abundance of nucleated erythrocytes in fetal liver $(8,34,44)$. These results are more consistent with $\mathrm{pRB}$ having a role in the differentiation of 
specific cell types, perhaps in regulating exit from a rapidly dividing state. As adults, mice heterozygous for the null $R b$ allele develop pituitary tumors with a loss of heterozygosity at the $R b$ locus (34), again suggesting a cell-specific function. The fact that CPE tumors have not been observed in these mice might mean that tumorigenesis induced by $T$ antigen requires a function(s) in addition to binding pRB. For example, if p107 or some other protein provides functional redundancy, the ability of $T$ antigen to bind both pRB and p107 would be critical for tumorigenesis. Our previous results also suggest the importance in CPE tumorigenesis of an amino-terminal activity (disrupted by deletion of T-antigen aa 17 to 27 ) which is distinct from $\mathrm{pRB} / \mathrm{p} 107$ binding (73). Perhaps both T-antigen activities must cooperate to produce tumors in the CPE.

Role of the $\mathrm{T}$-antigen $\mathrm{C}$ terminus in brain tumor progression. The $d l 1137$ protein induced abnormal growth of the CPE which was characteristic of wild-type $T$ antigen; however, by comparison, the phenotype was significantly delayed. This delay could have resulted from a slower or nonuniform rate of tumor growth or from the requirement for secondary cooperating genetic or epigenetic events. If the truncated protein encoded by $d l 1137$ is sufficient to induce tumorigenesis, one could expect all cells expressing this protein to be transformed and to participate uniformly in tumor growth, as was the case with wild-type $\mathrm{T}$ antigen in the CPE (6). On the other hand, if the absence of some critical T-antigen activity in $d l 1137$ results in insufficiency for tumor induction, requiring a compensating cellular change, abnormal growth properties should be observed only in those cells in which the secondary event took place. Thus, tumors should develop focally after a period of latency, which might vary depending on when the secondary event(s) occurs. The phenotype of LST1137 mice did not display these characteristics. Rather, the reproducible age at which full CPE expansion occurred (Fig. 2) and the uniform morphological progression of the tumors (Fig. 3) suggest that $d l 1137$ is sufficient to induce abnormal choroid plexus cell growth without dependence on cooperation.

The late phenotype did not reflect delayed onset of cell proliferation or a lower percentage of proliferating cells compared with wild-type $\mathrm{T}$-antigen mice, as evidenced from examination of the tissue for S-phase cells (Fig. 4). By 3 weeks of age, the normal nontransgenic choroid plexus is devoid of S-phase cells. In contrast, about $30 \%$ of the choroid plexus cells in a 3-week-old LST1137 mouse were in S phase, as evidenced from BrdU incorporation into nuclei. Consistent with morphological inspection, there were no signs of focal cell cycle activity. The fraction of S-phase cells remained constant at older ages when tumors were enlarged (4 months) and did not vary from that previously determined for wild-type $T$ antigen-expressing choroid plexus (6).

Hence, the tumors induced by $d l 1137$ appear to have a much lower growth rate than do those induced by wild-type $T$ antigen. Preliminary experiments suggest that the wild-type rate of tumorigenesis is restored upon interbreeding LST1137 mice and transgenic mice that do not develop CPE abnormalities (73) but which harbor a mutant $\mathrm{T}$ antigen (dl1135) containing an intact p53-binding C-terminal region (73a). Hence, some function in the $\mathrm{C}$-terminal four-fifths of $\mathrm{T}$ antigen has a role in regulating the rate of tumor formation, and that function may be the ability to bind p53. We are currently testing the hypothesis that $\mathrm{p} 53$ regulates the rate of epithelial cell tumor growth by measuring the rate of d11137-induced tumor growth in a p53 null mouse strain.

Current understanding of p53 function provides testable hypotheses which may explain its putative contribution to tumor growth rate. First, several recent observations suggest that p53 may have a role in cell cycle checkpoint control. For example, the levels of p53 increase in response to DNA damage-inducing agents (36) in correlation with $\mathrm{G}_{1}$ arrest (36, 40). Moreover, in several systems, conditional expression of p53 induces $G_{1}$ arrest $(15,40,55,75)$. In the absence of p53, $G_{1}$ arrest fails (36) and the genome becomes unstable $(48,79)$. Hence, p53 has been described as a "guardian of the genome," ensuring that only cells with intact genomes progress through cell division (41). Binding of p53 by wild-type $T$ antigen may release such a control and allow aberrant cells to progress through the cell cycle. Cells expressing the truncated dl1137 protein would be abnormally transformed but would retain normal p53 function and therefore may arrest or pause in $G_{1}$.

Another series of observations provide an alternative, perhaps complementary hypothesis to explain the slow growth of dl1137-induced CPE tumors. p53 has been shown to induce programmed cell death, or apoptosis, in cultured cells $(64,80$, 81 ), and thymocytes from p53 null mice fail to apoptose in response to irradiation $(9,50)$. Hence, one outcome of $\mathrm{p} 53$ induced growth arrest may be cell death (42). Since the rate of tumor growth reflects the balance of cell division and cell death, the p53-binding function of $T$ antigen may interfere with apoptosis of choroid plexus cells which is perhaps triggered by abnormal cell proliferation, resulting in rapidly growing tumors. The $d l 1137$ protein would be able to induce the apoptotic response but unable to interfere with this p53-mediated pathway, resulting in abundant cell death and slower overall growth of tumors. Morphological signs of apoptosis were in fact visible in LST1137 CPE (data not shown), although more rigorous analysis is required to determine how this compares with the phenotype induced by wild-type $T$ antigen. A similar mechanism has been described in cell culture experiments with the adenovirus transforming proteins. In response to the E1A protein (which, like $d l 1137$, binds pRB and p107), the cells undergo apoptosis, a phenomenon that seems to be mediated through p53 $(12,49)$. This response is inhibited by the E1B gene products $(12,49)$. Further study of the T-antigen transgenic mice will determine whether such a mechanism contributes to tumor progression in vivo.

p53-binding function correlates with lymphomagenesis induced by $T$ antigen. Our work with mutant $T$-antigen proteins suggests correspondence between the ability to bind p53 and the ability to induce lymphomagenesis. In an earlier study, a full-length mutant $\mathrm{T}$ antigen (5080) carrying a single amino acid change (Pro-584 to Leu) that renders a protein unable to bind p53 and pRB/p107 was impaired in lymphomagenesis (5). This protein was not completely inactive, since it induced hyperplasia (though not overt tumors) in the choroid plexus (5). In contrast, T-cell lymphoma was consistently induced by a T-antigen mutant ( $d l 1135)$ which retained binding to all three proteins but harbored a deletion of the amino-terminal-most transformation activity (73). Interestingly, the latter mutant appeared unable to induce B-cell tumors (73). Since $d l 1137$ binds pRB and p107 but not p53, it was critical to determine whether it had the capacity to induce lymphoma. As documented herein, neither B- nor T-cell tumors were produced in any of the founder LST1137 mice or their transgenic offspring. Spleens and thymuses were histologically normal in spite of demonstrable expression of the $d l 1137$ protein.

Since we previously characterized the progression of T-cell lymphoma induced by the $\mathrm{p} 53 / \mathrm{pRB} / \mathrm{p} 107$-binding form of $\mathrm{T}$ antigen (73), we were able to rule out any detectable abnormalities in the T-cell population of LST1137 mice. Mice that develop T-antigen-induced T-cell lymphoma begin to show an abnormal distribution of $T$ cells in the thymus after about 2 months of age. By 4 to 6 months of age, the mice show an 
overwhelming predominance of a single mature class of $\mathrm{T}$ cell (either $\mathrm{CD}^{+} \mathrm{CD}^{-}$or $\mathrm{CD} 4^{-} \mathrm{CD} 8^{+}$) in the thymus which is eventually often abundant in the spleen. FACS analysis demonstrated a normal thymocyte distribution in thymuses and a normal T-cell distribution in spleens of LST1137 mice of various ages. Moreover, whereas thymocytes from mice expressing the p53-binding form of $\mathrm{T}$ antigen are protected from irradiation-induced apoptosis, thymocytes from LST1137 mice apoptose normally (56). Because this same phenotype is produced in mice with a homozygous null mutation in p53 (9, 50 ), this result also supports the hypothesis that the p53binding function of $\mathrm{T}$ antigen leads to p53 inactivation. In fact, p53 null mice commonly develop T-cell lymphoma $(17,50)$, supporting the interpretation that elimination of $\mathrm{p} 53$ is a critical function of $\mathrm{T}$ antigen in tumorigenesis of this cell type. Since induction of lymphoma by $\mathrm{T}$ antigen clearly requires secondary events, unlike choroid plexus tumorigenesis, one possibility is that the p53-binding function disrupts a p53dependent surveillance pathway which under normal conditions would lead to the death of cells with accumulated mutations. Such a pathway could be essential in cells such as lymphocytes which undergo frequent DNA rearrangements. Disruption of $\mathrm{p} 53$ function, either by $\mathrm{T}$ antigen or by mutation, leads to survival of cells which have undergone secondary mutations that may lead to tumor progression.

In summary, the development of transgenic mice has facilitated the examination of certain cellular functions which are common targets for DNA virus transforming proteins. In this report, we suggest that the $\mathrm{pRB} / \mathrm{p} 107$-binding region of $\mathrm{T}$ antigen has an essential role in subverting choroid plexus cell growth control whereas the p53-binding function is dispensable. In contrast, a C-terminal T-antigen function, possibly p53 binding, is required to perturb normal lymphoid cell growth and may also be involved in accelerating the oncogenic process in the choroid plexus. Similar experiments in which various T-antigen mutants are directed to other specific cell types and developmental stages in transgenic mice, combined with the use of mice carrying null mutations in the cellular target genes, should yield a more complete analysis of these functions in tumorigenesis and development.

\section{ACKNOWLEDGMENTS}

We are grateful to Jim Pipas for introducing us to $d l 1137$, for providing other useful reagents, and for scientific discussion. We thank Marilyn Kozak for critical evaluation of the manuscript. Ronald Jaffe's expert assessment of choroid plexus abnormalities is much appreciated. Technical assistance of Tricia Ambroziak and Leonard Krall and valuable discussions with Ashok Srinivasan are greatly appreciated.

This work was supported by Public Health Service grants to T.V.D. from the NCI (CA46283) and the NIDDK (DK42910). T.V.D. is the recipient of an Research Career Development Award from the National Cancer Institute.

\section{REFERENCES}

1. Adams, J. M., and S. Cory. 1991. Transgenic models of tumor development. Science 254:1161-1167.

2. Bookstein, R., and W. Lee. 1991. Molecular genetics of the retinoblastoma suppressor gene. Crit. Rev. Oncogenesis 2:211227.

3. Buchkovich, K., L. A. Duffy, and E. Harlow. 1989. The retinoblastoma protein is phosphorylated during specific phases of the cell cycle. Cell 58:1097-1105.

4. Chen, J., K. Neilson, and T. Van Dyke. 1989. Lymphotropic papovavirus early region is specifically regulated in transgenic mice and efficiently induces neoplasia. J. Virol. 63:2204-2214.

5. Chen, J., G. Tobin, J. M. Pipas, and T. A. Van Dyke. 1992. T antigen mutant activities in transgenic mice: roles of p53 and
pRB-binding in tumorigenesis of the choroid plexus. Oncogene 7:1167-1175.

6. Chen, J., and T. Van Dyke. 1991. Uniform cell-autonomous tumorigenesis of the choroid plexus by papovavirus large $T$ antigens. Mol. Cell. Biol. 11:5968-5976.

7. Chen, P. L., P. Scully, J. Y. Shew, J. Y. Wang, and W. H. Lee. 1989. Phosphorylation of the retinoblastoma gene product is modulated during the cell cycle and cellular differentiation. Cell 58:11931198.

8. Clarke, A. R., E. R. Maandag, M. van Roon, N. M. T. van der Lugt, M. van der Valk, M. L. Hooper, A. Berns, and H. Te Riele. 1992 Requirement for a functional Rb-1 gene in murine development. Nature (London) 359:328-330.

9. Clarke, A. R., C. A. Purdie, D. J. Harrison, R. G. Morris, C. C. Bird, M. L. Hooper, and A. H. Wyllie. 1993. Thymocyte apoptosis induced by $\mathrm{p} 53$-dependent and independent pathways. Nature (London) 362:849-852.

10. Colby, W. W., and T. Shenk. 1982. Fragments of the simian virus 40 transforming gene facilitate transformation of rat embryo cells. Proc. Natl. Acad. Sci. USA 79:5189-5193.

11. Cooper, J. A., and P. Whyte. 1989. RB and the cell cycle: entrance or exit? Cell 58:1009-1011.

12. Debbas, M., and E. White. 1993. Wild-type p53 mediates apoptosis by E1A, which is inhibited by E1B. Genes Dev. 7:546-554.

13. DeCaprio, J. A., J. W. Ludlow, J. Figge, J. Y. Shew, C. M. Huang, W. H. Lee, E. Marsilio, E. Paucha, and D. M. Livingston. 1988. SV40 large tumor antigen forms a specific complex with the product of the retinoblastoma susceptibility gene. Cell 54:275-283.

14. DeCaprio, J. A., J. W. Ludlow, D. Lynch, Y. Furukawa, J. Griffin, H. Piwnica Worms, C. M. Huang, and D. M. Livingston. 1989. The product of the retinoblastoma susceptibility gene has properties of a cell cycle regulatory element. Cell 58:1085-1095.

15. Diller, L., J. Kassel, C. E. Nelson, M. A. Gryka, G. Litwak, M. Gebhardt, B. Bressac, M. Ozturk, S. J. Baker, B. Vogelstein, and S. H. Friend. 1990. p53 functions as a cell cycle control protein in osteosarcomas. Mol. Cell. Biol. 10:5772-5781.

16. Dobbelstein, M., A. K. Arthur, S. Dehde, K. van Zee, A. Dickmanns, and E. Fanning. 1992. Intracistronic complementation reveals a new function of SV40 T antigen that co-operates with $\mathrm{Rb}$ and p53 binding to stimulate DNA synthesis in quiescent cells. Oncogene 7:837-847.

17. Donehower, L. A., M. Harvey, B. L. Slagle, M. J. McArthur, C. A. J. Montgomery, J. S. Butel, and A. Bradley. 1992. Mice deficient for $\mathrm{p} 53$ are developmentally normal but susceptible $\mathrm{t}$ spontaneous tumours. Nature (London) 356:215-221.

18. Dowdy, S. F., P. W. Hinds, K. Louie, S. I. Reed, A. Arnold, and R. A. Weinberg. 1993. Physical interaction of the retinoblastoma protein with human D cyclins. Cell 73:499-511.

19. Dyson, N., K. Buchkovich, P. Whyte, and E. Harlow. 1989. The cellular $107 \mathrm{~K}$ protein that binds to adenovirus E1A also associates with the large T antigens of SV40 and JC virus. Cell 58:249-255.

20. Erselius, J. R., B. Jostes, A. K. Hatzopoulos, L. Mosthaf, and P. Gruss. 1990. Cell-type-specific control elements of the lymphotropic papovavirus enhancer. J. Virol. 64:1657-1666.

21. Ewen, M. E., J. W. Ludlow, E. Marsilio, J. A. DeCaprio, R. C. Millikan, S. H. Cheng, E. Paucha, and D. M. Livingston. 1989. An $\mathrm{N}$-terminal transformation-governing sequence of SV40 large T antigen contributes to the binding of both $\mathrm{p} 110 \mathrm{Rb}$ and a second cellular protein, p120. Cell 58:257-267.

22. Ewen, M. E., H. K. Sluss, C. J. Sherr, H. Matsushime, J. Kato, and D. M. Livingston. 1993. Functional interactions of the retinoblastoma protein with mammalian D-type cyclins. Cell 73:487-497.

23. Fanning, E. 1992. Modulation of cellular growth control by SV40 large $T$ antigen, p. 1-19. In W. Doerfler and P. Bohm (ed.), Malignant transformation by DNA viruses. $\mathrm{VCH}$, Weinheim, Germany.

24. Garvin, A. M., K. M. Abraham, K. A. Forbush, A. G. Farr, B. L. Davison, and R. M. Perlmutter. 1990. Disruption of thymocyte development and lymphomagenesis induced by SV40 T-antigen. Int. Immunol. 2:173-180.

25. Goodrich, D. W., N. Ping Wang, Y. Qian, E. Y.-H. Lee, and W. Lee. 1991. The retinoblastoma gene product regulates progression through the G1 phase of the cell cycle. Cell 67:293-302. 
26. Gurney, E. G., R. O. Harrison, and J. Fenno. 1980. Monoclonal antibodies against simian virus $40 \mathrm{~T}$ antigens: evidence for distinct subclasses of large $\mathrm{T}$ antigen and for similarities among nonviral $\mathrm{T}$ antigens. J. Virol. 34:752-763.

27. Hamel, P. A., B. L. Gallie, and R. A. Phillips. 1992. The retinoblastoma protein and cell cycle regulation. Trends Genet. 8:180185.

28. Hanahan, D. 1988. Dissecting multistep tumorigenesis in transgenic mice. Annu. Rev. Genet. 22:479-519.

29. Hanahan, D. 1989. Transgenic mice as probes into complex systems. Science 246:1265-1275.

30. Harlow, E. L., V. Crawford, D. C. Pim, and N. M. Williamson. 1981. Monoclonal antibodies specific for simian virus 40 tumor antigens. J. Virol. 39:861-869.

31. Hinds, P. W., S. Mittnacht, V. Dulic, A. Arnold, S. I. Reed, and R. A. Weinberg. 1992. Regulation of retinoblastoma protein functions by ectopic expression of human cyclins. Cell 70:9931006.

32. Hogan, B., F. Costantini, and E. Lacy. 1986. Manipulating the mouse embryo. Cold Spring Harbor Laboratory, Cold Spring Harbor, N.Y.

33. Hollingsworth, R. E., Jr., C. E. Hensey, and W. Lee. 1993. Retinoblastoma protein and the cell cycle. Curr. Opin. Genet. Dev. 50:55-62.

34. Jacks, T., A. Fazeli, E. M. Schmitt, R. T. Bronson, M. A. Goodell, and R. A. Weinberg. 1992. Effects of an Rb mutation in the mouse. Nature (London) 359:295-300.

35. Kalderon, D., and A. E. Smith. 1984. In vitro mutagenesis of a putative DNA binding domain of SV40 large-T. Virology 139:109137.

36. Kastan, M. B., O. Onyekwere, D. Sidransky, B. Vogelstein, and R. W. Craig. 1991. Participation of p53 protein in the cellular response to DNA damage. Cancer Res. 51:6304-6311.

37. Kiernan, J. A. 1990. Histological and histochemical methods. Theory and practice. Pergamon Press, Inc., Elmsford, N.Y.

38. Kierstead, T. D., and M. J. Tevethia. 1993. Association of p53 binding and immortalization of primary C57BL/6 mouse embryo fibroblast by using simian virus $40 \mathrm{~T}$-antigen mutants bearing internal overlapping deletion mutations. J. Virol. 67:1817-1829.

39. Kohrman, D. C., and M. J. Imperiale. 1992. Simian virus 40 large $\mathrm{T}$ antigen stably complexes with a 185 -kilodalton host protein. J. Virol. 66:1752-1760.

40. Kuerbitz, S. J., B. S. Plunkett, W. V. Walsh, and M. B. Kastan. 1992. Wild-type p53 is a cell cycle checkpoint determinant following irradiation. Proc. Natl. Acad. Sci. USA 89:7491-7495.

41. Lane, D. P. 1992. p53, guardian of the genome. Nature (London) 358:15-16.

42. Lane, D. P. 1993. A death in the life of p53. Nature (London) 362:786-787.

43. Lanford, R. E., C. Wong, and J. S. Butel. 1985. Differential ability of a $\mathrm{T}$-antigen transport-defective mutant of simian virus 40 to transform primary and established rodent cells. Mol. Cell. Biol. 5:1043-1050.

44. Lee, Y. H. P., C. Chang, N. Hu, Y. J. Wang, C. Lai, K. Herrup, W. Lee, and A. Bradley. 1992. Mice deficient for Rb are nonviable and show defects in neurogenesis and haematopoiesis. Nature (London) 359:288-294.

45. Levine, A., J. Momand, and C. Finlay. 1991. The p53 tumour suppressor gene. Nature (London) 351:453-456.

46. Levine, A. J. 1990 . The p 53 protein and its interactions with the oncogene products of the small DNA tumor viruses. Virology 177:419-426.

47. Livingston, D., and E. Mihich. 1992. Third Annual Pezcoller Symposium: Tumor Suppressor Genes. Cancer Res. 52:32463249.

48. Livingstone, L. R., A. White, J. Sprouse, E. Livanos, T. Jacks, and T. D. Tlsty. 1992. Altered cell cycle arrest and gene amplification potential accompany loss of wild-type p53. Cell 70:923-935.

49. Lowe, S. W., and H. E. Ruley. 1993. Stabilization of the p53 tumor suppressor is induced by adenovirus $5 \mathrm{E} 1 \mathrm{~A}$ and accompanies apoptosis. Genes Dev. 7:535-545.

50. Lowe, S. W., E. M. Schmitt, S. W. Smith, B. A. Osborne, and T. Jacks. 1993. p53 is required for radiation-induced apoptosis in mouse thymocytes. Nature (London) 362:847-849.

51. Manfredi, J. J., and C. Prives. 1990. Binding of p53 and p105-RB is not sufficient for oncogenic transformation by a hybrid polyomavirus-simian virus 40 large $T$ antigen. J. Virol. 64:5250-5259.

52. Mares, V., and Z. Lodin. 1974. An autoradiographic study of DNA synthesis in adolescent and adult mouse forebrain. Brain Res. 76:557-561.

53. Marshall, C. J. 1991. Tumor suppressor genes. Cell 64:313-326.

54. Marsilio, E., S. H. Cheng, B. Schaffhausen, E. Paucha, and D. M. Livingston. 1991. The $T / t$ common region of simian virus 40 large $T$ antigen contains a distinct transformation-governing sequence. J. Virol. 65:5647-5652.

55. Martinez, J., I. Georgoff, and A. J. Levine. 1991. Cellular localization and cell cycle regulation by a temperature-sensitive p53 protein. Genes Dev. 5:151-159.

56. McCarthy, S. A., H. S. Symonds, and T. Van Dyke. Regulation of apoptosis in transgenic mice by SV40 T antigen-mediated inactivation of p53. Proc. Natl. Acad. Sci. USA, in press.

57. Mole, S. E., J. V. Gannon, M. J. Ford, and D. P. Lane. 1987. Structure and function of SV40 large T antigen. Proc. R. Soc. London Ser. B 317:455-469.

58. Moran, E. 1993. DNA tumor virus transforming proteins and the cell cycle. Curr. Opin. Genet. Dev. 50:63-70.

59. Palmiter, R. D., and R. L. Brinster. 1986. Germ line transformation of mice. Annu. Rev. Genet. 20:465-499.

60. Perry, M. E., and A. J. Levine. 1993. Tumor-suppressor p53 and the cell cycle. Curr. Opin. Genet. Dev. 3:50-54.

60a.Pipas, J. Unpublished data.

61. Pipas, J. M., K. W. Peden, and D. Nathans. 1983. Mutational analysis of simian virus $40 \mathrm{~T}$ antigen: isolation and characterization of mutants with deletions in the T-antigen gene. Mol. Cell. Biol. 3:203-213.

62. Prives, C., and J. J. Manfredi. 1993. The p53 tumor suppressor protein: meeting review. Genes Dev. 7:529-534.

63. Schmieg, F. I., and D. T. Simmons. 1988. Characterization of the in vitro interaction between SV40 T antigen and p53: mapping the p53 binding site. Virology 164:132-140.

64. Shaw, P., R. Bovey, S. Tardy, R. Sahli, B. Sordat, and J. Costa. 1992. Induction of apoptosis by wild-type p53 in a human colon tumor-derived cell line. Proc. Natl. Acad. Sci. USA 89:4495-4499.

65. Small, J. A., C. Bieberich, Z. Ghotbi, J. Hess, G. A. Scangos, and J. E. Clements. 1989. The visna virus long terminal repeat directs expression of a reporter gene in activated macrophages, lymphocytes, and the central nervous systems of transgenic mice. J. Virol. 63:1891-1896.

66. Sompayrac, L., and K. J. Danna. 1988. A new SV40 mutant that encodes a small fragment of $\mathrm{T}$ antigen transforms established rat and mouse cells. Virology 163:391-396.

67. Sompayrac, L., and K. J. Danna. 1991. The amino-terminal 147 amino acids of SV40 large T antigen transform secondary rat embryo fibroblasts. Virology 181:412-415.

68. Sompayrac, L., and K. J. Danna. 1992. An amino-terminal fragment of SV40 T antigen transforms REF52 cells. Virology 191: $439-442$.

69. Spector, R., and C. E. Johanson. 1989. The mammalian choroid plexus. Sci. Am. 261:68-74.

70. Srinivasan, A., K. W. C. Peden, and J. M. Pipas. 1989. The large tumor antigen of simian virus 40 encodes at least two distinct transforming functions. J. Virol. 63:5459-5463.

70a.Srinivasan, A., J. M. Pipas, M. T. Saenz Robles, and T. Van Dyke. Unpublished data.

71. Suda, Y., S. Aizawa, S. Hirai, T. Inoue, Y. Furuta, M. Suzuki, S. Hirohashi, and Y. Ikawa. 1987. Driven by the same Ig enhancer and SV40 T promoter ras induced lung adenomatous tumors, myc induced pre-B cell lymphomas and SV40 large T gene a variety of tumors in transgenic mice. EMBO J. 6:4055-4065.

72. Symonds, H., J. Chen, and T. Van Dyke. 1991. Complex formation between the lymphotropic papovavirus large tumor antigen and the tumor suppressor protein, p53. J. Virol. 65:5417-5424.

73. Symonds, H. S., S. A. McCarthy, J. Chen, J. M. Pipas, and T. Van Dyke. 1993. Use of transgenic mice reveals cell-specific transformation by a simian virus $40 \mathrm{~T}$-antigen amino-terminal mutant. Mol. Cell. Biol. 13:3255-3265. 
73a.Symonds, H. S., and T. Van Dyke. Unpublished data

74. Thompson, D. L., D. Kalderon, A. E. Smith, and M. J. Tevethia. 1990. Dissociation of Rb-binding and anchorage-independent growth from immortalization and tumorigenicity using SV40 mutants producing $\mathrm{N}$-terminally truncated large $\mathrm{T}$ antigens. Virology 178:15-34.

75. Ullrich, S. J., W. E. Mercer, and E. Appella. 1992. Human wild-type p53 adopts a unique conformational and phosphorylation state in vivo during growth arrest of glioblastoma cells. Oncogene 7:1635-1643.

76. Van Dyke, T. A. 1994. Analysis of viral-host protein interactions and tumorigenesis in transgenic mice. Semin. Cancer Biol. 5:106.1-106.14

77. Weinberg, R. A. 1991. Tumor suppressor genes. Science 254:11381146.

78. Yaciuk, P., M. C. Carter, J. M. Pipas, and E. Moran. 1991. Simian virus 40 large-T antigen expresses a biological activity complementary to the p300-associated transforming function of the adenovirus E1A gene products. Mol. Cell. Biol. 11:2116-2124.

79. Yin, Y., M. A. Tainsky, F. Z. Bischoff, L. C. Strong, and G. M. Wahl. 1992. Wild-type p53 restores cell cycle control and inhibits gene amplification in cells with mutant p53 alleles. Cell 70:937948.

80. Yonish-Rouach, E., D. Grunwald, S. Wilder, A. Kimchi, E. May, J. Lawrence, P. May, and M. Oren. 1993. p53-Mediated cell death: relationship to cell cycle control. Mol. Cell. Biol. 13:1415-1423.

81. Yonish-Rouach, E., D. Resnitzky, J. Lotem, L. Sachs, A. Kimchi, and M. Oren. 1991. Wild-type p53 induces apoptosis of myeloid leukaemic cells that is inhibited by interleukin-6. Nature (London) 352:345-340.

82. Zhu, J., M. Abate, P. W. Rice, and C. N. Cole. 1991. The ability of simian virus 40 large $\mathrm{T}$ antigen to immortalize primary mouse embryo fibroblasts cosegregates with its ability to bind to $\mathrm{p} 53$. J. Virol. 65:6872-6880.

83. Zhu, J., P. L. Rice, L. Gorsch, M. Abate, and C. N. Cole. 1992. Transformation of a continuous rat embryo fibroblast cell line requires three separate domains of simian virus 40 large $T$ antigen. J. Virol. 66:2780-2791.

84. Zhu, L., S. van den Heuvel, K. Helin, A. Fattaey, M. Ewen, D. Livingston, N. Dyson, and E. Harlow. 1993. Inhibition of cell proliferation by $\mathrm{p} 107$, a relative of the retinoblastoma protein. Genes Dev. 7:1111-1125. 